\title{
Exogenous melatonin enhances salt stress tolerance in tomato seedlings
}

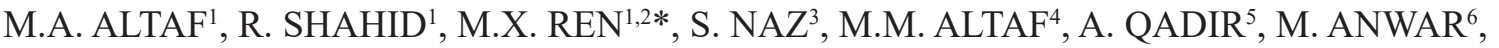 \\ A. SHAKOOR ${ }^{7}$, and F. HAYAT ${ }^{8}$ \\ School of Life and Pharmaceutical Sciences, Hainan University, Haikou 570228, P.R. China ${ }^{1}$ \\ Center for Eco-Environmental Restoration Engineering of Hainan University, Haikou, 570228, P.R. China ${ }^{2}$ \\ Faculty of Agricultural Science and Technology, Bahauddin Zakariya University Multan 60800, Pakistan ${ }^{3}$ \\ College of Ecology and Environment, Hainan University, Haikou 570228, P.R. China ${ }^{4}$ \\ Agricultural Training Institute, Karor, Layyah, Punjab, Pakistan ${ }^{5}$ \\ College of Life Sciences and Oceanography, Shenzhen University, Shenzhen 518060, P.R. China ${ }^{6}$ \\ Department of Environment and Soil Sciences, University of Lleida, E-25198 Lleida, Spain ${ }^{7}$ \\ College of Horticulture, Nanjing Agriculture University, Nanjing 210095, P.R. China ${ }^{8}$
}

\begin{abstract}
Melatonin (N-acetyl-5-methoxytryptamine) is an essential molecule which regulates plant growth and development and alleviates the damaging effects of abiotic stresses. To evaluate the important functions of melatonin in response to salinity stress, the effects of exogenous melatonin on the antioxidant system and growth of tomato (Solanum lycopersicum L.) under $150 \mathrm{mM} \mathrm{NaCl}$ stress were investigated. The application of $100 \mu \mathrm{M}$ melatonin compensated the growth inhibition caused by salt-stress. Melatonin treated seedlings had an increased fresh and dry masses of shoots and roots. The application of 1 - $200 \mu \mathrm{M}$ melatonin notably enhanced the relative chlorophyll content (SPAD index), root characteristics, and gas exchange in tomato seedlings subjected to salt stress compared to seedlings treated with salt stress alone. Moreover, melatonin pretreatment minimized accumulation of reactive oxygen species and improved activities of antioxidative enzymes including catalase, superoxide dismutase, glutathione reductase, and ascorbate peroxidase.
\end{abstract}

Additional key words: abiotic stresses, antioxidative enzymes, chlorophyll, $\mathrm{NaCl}$, oxidative damage, photosynthesis.

\section{Introduction}

Environmental stress, such as salinity, directly impacts plants growth and development through osmotic and particular ion effects, and by leading to oxidative stress due to enhanced reactive oxygen species (ROS) production (Hasanuzzaman et al. 2013, Jiang et al. 2017). According to Ahuja (2010) and Zhang et al. (2011), many environmental stresses as drought, salinity, extreme temperatures are devastating for crops causing yield loses. Kaya et al. (2013) and Peng et al. (2017) declared soil salinity as a global problem. As described by Khan and Hemalatha (2016) and Liu et al. (2018) photosystems get impaired, production of reactive oxygen species is accelerated, and growth is reduced due to excessive $\mathrm{NaCl}$ concentration. Firstly, cellular organelles are damaged due to high concentrations of $\mathrm{Na}^{+}$, thus causing changes in of enzymatic activities, protein synthesis, respiration, and photosynthesis. Secondly, an imbalance in nutrients is resulted due to salinity, as it causes a decline in uptake and transport nutrients towards the shoot. Further, plants face a physiological drought condition as salinity hurdles root water uptake due to decreased osmotic potential of soil (Ruiz-Lozano et al. 2012).

Melatonin (N-acetyl-5-methoxytryptamine) is an organic compound with low molecular mass and exerting various biological activities; it represents a ubiquitous molecule in all living organisms from bacteria to mammals (Hardeland et al. 2011, Reiter et al. 2014, Nawaz et al. 2016). The first discovery of melatonin in higher plants was reported by Dubbels et al. (1995) and Hattori et al. (1995). Later on, clear occurrence of melatonin in all organs of

Submitted 23 April 2020, last revision 4 June 2020, accepted 9 June 2020.

Abbreviations: APX - ascorbate peroxidase; CAT - catalase; $\mathrm{c}_{\mathrm{i}}$ - intercellular $\mathrm{CO}_{2}$ concentration; E - transpiration rate; EL - electrolyte leakage; GR - glutathione reductase; $g_{s}$ - stomatal conductance; MDA - malondialdehyde; PDM - plant dry mass; PFM - plant fresh mass; $\mathrm{P}_{\mathrm{N}}$ - net photosynthetic rate; RDM - root dry mass; RFM - root fresh mass; ROS - reactive oxygen species; SOD - superoxide dismutase.

Acknowledgments: We would like to thank Wang Zhiwei from the College of Horticulture and Landscape Architecture, Hainan University, Haikou for his kind guidance and laboratory equipment. This program was financially supported by the Innovative Team Program of Hainan Natural Science Foundation (2018CXTD334) and the National Natural Science Foundation of China (41871041).

* Corresponding author; e-mail: renmx@hainu.edu.cn 
plants including fruits, leaves, flowers, stems, seeds and roots has been evidenced (Arnao and Hernández-Ruiz 2015). The beneficial role of melatonin has been proved by increasing number of reports. The useful role of this magic molecule has been confirmed in many plant processes including germination of seeds and seedling growth (Aguilera et al. 2015, Li et al. 2019a), germplasm storage (Zhao et al. 2011, Uchendu et al. 2013), development and growth of roots (Hernandez-Ruiz et al. 2005, Park and Back 2012); and in responses to many stress conditions including high temperature stress (Jahan et al. 2019), salt stress (Liu et al. 2019, Li et al. 2019c, Zhang et al. 2019), drought stress (Wang et al. 2013, Liang et al. 2019, Yang et al. 2019b), cold stress (Bajwa et al. 2014, Cao et al. 2019), heavy metals (Kaya et al. 2019), pathogens (Wei et al. 2017), and ultraviolet radiation (Afreen et al. 2006, Wei et al. 2019). Melatonin has multiple functions in plants, though, its possible role under abiotic stresses is still uncertain (Siddiqui et al. 2019). Yin et al. (2019) described its protective ability against abiotic stress in plants. Li et al. (2019b) suggested the involvement of melatonin in enhancing tolerance under both biotic and abiotic stresses in tomato plants, by regulation of several biological processes. Galano et al. (2011), Zhang et al. (2015), and Zhang et al. (2019) also witnessed the efficiency of exogenous melatonin in different crops for the amelioration of adverse effects of different stresses. Many other exogenous substances can be employed for improving productivity and enhancing tolerance in plants under stress conditions (Yang et al. 2015, Han et al. 2016). The following factors seemed to affect alleviating effects of melatonin: improvement in photosynthetic capacity, inhibition of chlorophyll degradation, enhancement of growth parameters and activities of antioxidant enzymes, and development of root morphology-related characteristics.

The tomato (Solanum lycopersicum L.) is moderately sensitive towards salinity stress (Liu et al. 2015b). The current study was conducted to study the role of melatonin under salinity stress conditions on photosynthetic rate, root traits, response to oxidative stress and seedling health. The outcome of this study would contribute to the existing literature on the role of melatonin in plants. It would guide the cultivation faculty of vegetables with improved quality and better yields.

\section{Materials and methods}

Plants, growth conditions, and treatments: The seeds of tomato (Solanum lycopersicum L.) cv. Fenli were purchased from a seed store in Shouguang Minghao Seed Industry Co. (Shouguang, China). The melatonin (N-acetyl5-methoxytryptamine) was purchased from Solarbio, (Haikou, Hainan, China). The $\mathrm{NaCl}$ was purchased from Xilong Scientific Co.) Haikou, Hainan, China.

The current study was conducted in the Hainan University of Haikou City, China (a.s.1. 14 m). Tomato seed were sowed into moistened Vermiculite in plug trays. After germination, tomato seedlings at 3 true-leaves stage
(35 d after sowing) were transfer into plastic pots (top diameter of $10 \mathrm{~cm}$, height of $8.5 \mathrm{~cm}$, and bottom diameter of $7 \mathrm{~cm}$ ) also filled with Vermiculite $(12 \mathrm{~g})$. The seedlings were pre-cultivated for $10 \mathrm{~d}$ to allow the adaption to new conditions. This study was carried out under controlled conditions (day/night temperatures of $24 / 13{ }^{\circ} \mathrm{C}$, a relative humidity between $65-85 \%$, a photosynthetic photon flux density of $350 \mu \mathrm{mol} \mathrm{m}^{-2} \mathrm{~s}^{-1}$ and a 15 -h photoperiod.

Then various concentrations of melatonin $(0,1,50$, 100,150 , and $200 \mu \mathrm{M} ; 80 \mathrm{~cm}^{3}$ per plant) were applied directly into the soil for $12 \mathrm{~d}$ (once every third day). After $12 \mathrm{~d}$ of melatonin pretreatment, seedlings were irrigated with $150 \mathrm{mM} \mathrm{NaCl}\left(80 \mathrm{~cm}^{3}\right.$ per plant $)$. Cntrol plants were irrigated with distilled water without the addition of $\mathrm{NaCl}$ or melatonin. There were three replicates for each treatment, each containing ten plants. The seedlings were treated with $\mathrm{NaCl}$ for $12 \mathrm{~d}$ and samples for calculating different parameters were collected. Quick freezing of samples was done by adding liquid nitrogen and the samples were stored at $-80^{\circ} \mathrm{C}$.

Growth parameters and root morphology: Plant height was calculated after salt and melatonin treatment for $12 \mathrm{~d}$. Fresh mass from 6 identical plants was determined on an electric balance (MSE24P-1-CE-DA, Cubis ${ }^{\circledR}$, Sortorious, Göttingen, Germany). For measuring dry mass, seedlings were dried in an oven, first at $105^{\circ} \mathrm{C}$ for $15 \mathrm{~min}$ and then at $70{ }^{\circ} \mathrm{C}$ for $72 \mathrm{~h}$.

Root harvesting was done by picking three uniform plants. Roots were washed with deionized water. Imagery scan screen (Epson Expression 11000XL, Regent Instruments, Canada) was used to perform root scanning. Further, WinRHIZO 2003 a software (Regent Instruments) was used for root image analysis.

Measurement of chlorophyll content, carotenoid content, leaf photosynthesis parameters and SPAD index: Cold acetone $\left(80 \%, \mathrm{~m} / \mathrm{v}, 10 \mathrm{~cm}^{3}\right)$ was used for the extraction of chlorophyll from fresh leaves $(0.5 \mathrm{~g})$, followed by centrifugation of homogenate (5 $000 \mathrm{~g}$, 10 min). Lichtenhaler and Wellburn method (1983) was used to determine chlorophyll $a$, chlorophyll $b$, and carotenoid content spectrophotometrically, and absorbance was recorded at 662, 645, and $470 \mathrm{~nm}$, respectively. A SPAD-502 chlorophyll meter (Minolta Camera Co., Osaka, Japan) was used for measuring relative chlorophyll content of tomato leaves (every $3^{\text {rd }}$ leaf was selected from top of each plant). A portable photosynthesis system (CIRAS-3, Hansatech Co., Amesbury, MA, USA) was used to measure net photosynthetic rate $\left(\mathrm{P}_{\mathrm{N}}\right)$, transpiration rate $(\mathrm{E})$, stomatal conductance $\left(\mathrm{g}_{\mathrm{s}}\right)$, and intercellular $\mathrm{CO}_{2}$ concentration $\left(\mathrm{c}_{\mathrm{i}}\right)$, of the fully expanded leaves. All measurements were performed under a leaf temperature of $25 \pm 2{ }^{\circ} \mathrm{C}$, a relative humidity of $65 \pm 5 \%$, a photosynthetic photon flux density of $800 \mu \mathrm{mol} \mathrm{m} \mathrm{m}^{-2} \mathrm{~s}^{-1}$, and external $\mathrm{CO}_{2}$ concentration of $360 \mu \mathrm{mol} \mathrm{mol}{ }^{-1}$.

Determination of $\mathrm{H}_{2} \mathrm{O}_{2}, \mathrm{O}_{2}{ }^{--}$, malondialdehyde, and electrolyte leakage in leaves: Heath and Packer's method (1968) was followed to measure the end product of lipid 
peroxidation (malondialdehyde, MDA). In leaf samples, a solution consisting of $0.65 \%(\mathrm{~m} / \mathrm{v})$ 2-thiobarbituric acid and $10 \%(\mathrm{~m} / \mathrm{v})$ trichloroacetic acid was used for extraction purposes.

Similarly, a modified method of Velikova et al. (2000) was employed for $\mathrm{H}_{2} \mathrm{O}_{2}$ determination. For this purpose, homogenate of leaf tissues $(0.07 \mathrm{~g})$ was prepared by using $5 \%$ trichloroacetic acid solution, then it was centrifuged (12 $000 \mathrm{~g}, 15 \mathrm{~min})$. After centrifugation, potassium phosphate buffer $\left(0.5 \mathrm{~cm}^{3}, \mathrm{pH} 7\right)$ and KI $\left(1 \mathrm{~cm}^{3}\right)$ were added to $0.5 \mathrm{~cm}^{3}$ supernatant, and absorbance was measured at $390 \mathrm{~nm}$. Finally, a standard curve was followed to estimate $\mathrm{H}_{2} \mathrm{O}_{2}$ content.

A modified method of Elstner and Heupel (1976) was employed for estimating superoxide in leaves by homogenizing leaf sample $(0.5 \mathrm{~g})$ with potassium phosphate buffer $\left(3 \mathrm{~cm}^{3}, \mathrm{pH} 7.8\right)$. After centrifuging the homogenate, phosphate buffer $\left(0.9 \mathrm{~cm}^{3}, \mathrm{pH} 7.8\right)$, and hydroxylamine hydrochloride $\left(0.1 \mathrm{~cm}^{3}\right)$ were added to $1 \mathrm{~cm}^{3}$ supernatant, and incubated at $25^{\circ} \mathrm{C}$ for $20 \mathrm{~min}$, followed by addition of sulfanilamide and $\alpha$-naphthylamine. Then, centrifugation was done (15 $000 \mathrm{~g}, 5 \mathrm{~min})$ after adding the same volume of ethyl ether, and absorbance was measured at $530 \mathrm{~nm}$. Finally, production rate of superoxide was calculated by using sodium nitrite as a standard solution.

The method of Zhang et al. (2012a) was used for measuring electrolyte leakage (EL) of leaves. Into $10 \mathrm{~cm}^{3}$ of distilled deionized water in a test tube, $100 \mathrm{mg}$ of fresh leaf sample was added. After two hours, an initial electrical conductivity was measured (ECI). Then, for measuring the final electrical conductivity (ECII), the eaction tube was boiled about $20 \mathrm{~min}$ followed by cooling at $25^{\circ} \mathrm{C}$. We also measured the electrical conductivity of water (ECIII). Finally, a following formula was used for calculation: $\mathrm{EL}[\%]=100 \times(\mathrm{ECI}-\mathrm{ECIII}) /($ ECII $-\mathrm{ECIII})$.

Determination of antioxidant enzyme activities: Before performing enzymes assay, an ice-chilled extraction buffer consisting of $1 \mathrm{mM}$ EDTA, $1.5 \%(\mathrm{~m} / \mathrm{v})$ polyvinylpyrrolidone, $50 \mathrm{mM}$ Tris- $\mathrm{HCl}$, and $1 \mathrm{mM} \mathrm{MgCl}$ ( $\mathrm{pH}$ of 7.8) was used for homogenization of seedling samples collected from each treatment. For determining ascorbate peroxidase (APX), a crude extract was prepared by adding $2 \mathrm{mM}$ of ascorbate (ASC). Centrifugation of homogenates was carried out at $13000 \mathrm{~g}$ and $4{ }^{\circ} \mathrm{C}$ for $20 \mathrm{~min}$, the supernatant was used for assay of enzymes activities, such as catalase (CAT), APX, superoxide dismutase (SOD), and glutathione reductase (GR). The activities of CAT, APX, SOD, and GR were measured following the method of Aebi (1984), Nakano and Asada (1981), Beyer and Fridovich (1987), and Foyer and Halliwell (1976), respectively. The enzyme amount required to convert one $\mu$ mole of substrate in one minute is equal to 1 Unit of a respective enzyme.

Analysis of data: SPSS statistical software (IBM SPSS 22.0, IBM Corporation, New York, USA) was used for performing statistical analysis. Means \pm SEs of three replicates were used to present the data. Duncan's multiple tests $(P<0.05)$ was employed for analyzing the difference between treatments. Originpro $2020 b$ (Originlab Corp., Northampton, MA, USA) software was used to perform the hierarchical cluster analysis (complete clustering algorithm) and making a dendrogram among studied parameters. Figures were also produced using Originpro $2020 b$ software.

\section{Results}

The plant height was significantly decreased (of about $37 \%$ ) after the addition of $\mathrm{NaCl}$ as compared to control (Fig. 1). Pretreatment with $0,1,50,100,150$, and $200 \mu \mathrm{M}$ melatonin alleviate the growth inhibition. The melatonin application (at a rate of $100 \mu \mathrm{M}$ ) also alleviate negative effect of $\mathrm{NaCl}$ on root and whole plant fresh and dry masses (Fig. 2).

Compared with control, net photosynthetic rate, transpiration rate, stomatal conductance, and intercellular $\mathrm{CO}_{2}$ concentration were significantly reduced by salt stress (Fig. 3). However, this salt stress-induced reduction in $\mathrm{P}_{\mathrm{N}}$, $\mathrm{c}_{\mathrm{i}}, \mathrm{gs}$, and $\mathrm{E}$ was alleviated with melatonin pretreatment at various concentrations $(1-200 \mu \mathrm{M})$ and the most effective concentration was $100 \mu \mathrm{M}$. For example, melatonin pretreated tomato seedlings at $100 \mu \mathrm{M}$ concentration followed by salt stress exhibited a decrease in $\mathrm{P}_{\mathrm{N}}, \mathrm{c}_{\mathrm{i}}, \mathrm{g}_{\mathrm{s}}$, and $\mathrm{E}$ by $80.5,83.6,36.8$, and $82.5 \%$, respectively, as compared with salt stress without pretreatment. Likewise, salt treatment reduced chlorophyll $a$, chlorophyll $b$, and carotenoid content, and this salt stress-induced reduction was alleviated by melatonin pretreatment (Fig. 4A-C). A dramatic decrease was shown in the SPAD index (relative chlorophyll content index) after 12-d treatment with $\mathrm{NaCl}$, from 48.03 in control plants to 36.84 in the salt-stressed plant, while at $100 \mu \mathrm{M}$ melatonin-pretreated plants it was 45.53 (Fig. 4D).

The decrease of total root volume, root length, root

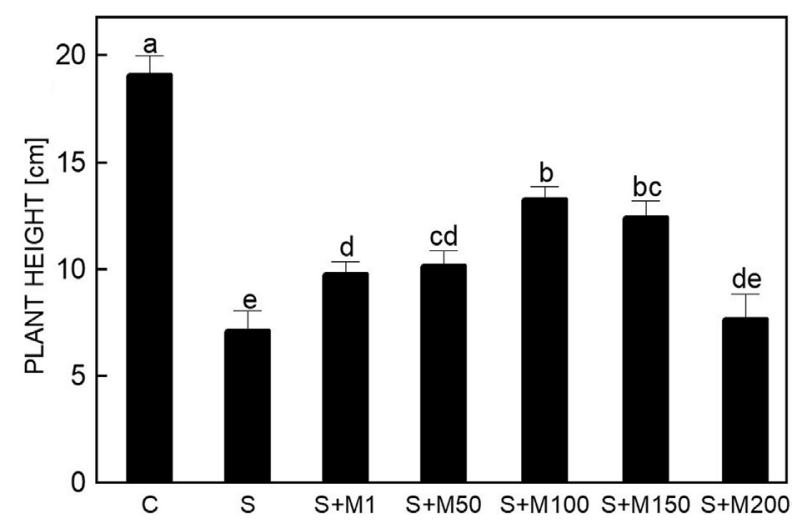

Fig. 1. Influence of $\mathrm{NaCl}$ alone or in combination with various concentrations of melatonin in tomato seedlings on plant height. $\mathrm{C}$ - control, S - $150 \mathrm{mM} \mathrm{NaCl}, \mathrm{S}+\mathrm{M} 1-150 \mathrm{mM} \mathrm{NaCl}+1 \mu \mathrm{M}$ melatonin, $\mathrm{S}+\mathrm{M} 50-150 \mathrm{mM} \mathrm{NaCl}+50 \mu \mathrm{M}$ melatonin, $\mathrm{S}+\mathrm{M} 100$ $-150 \mathrm{mM} \mathrm{NaCl}+100 \mu \mathrm{M}$ melatonin, $\mathrm{S}+\mathrm{M} 150-150 \mathrm{mM} \mathrm{NaCl}$ $+150 \mu \mathrm{M}$ melatonin, $\mathrm{S}+\mathrm{M} 200-150 \mathrm{mM} \mathrm{NaCl}+200 \mu \mathrm{M}$ melatonin. Means \pm SEs, $n=3$, significant differences are marked by different lowercase letters (at $P<0.05$ ) according to Duncan's multiple range test. 


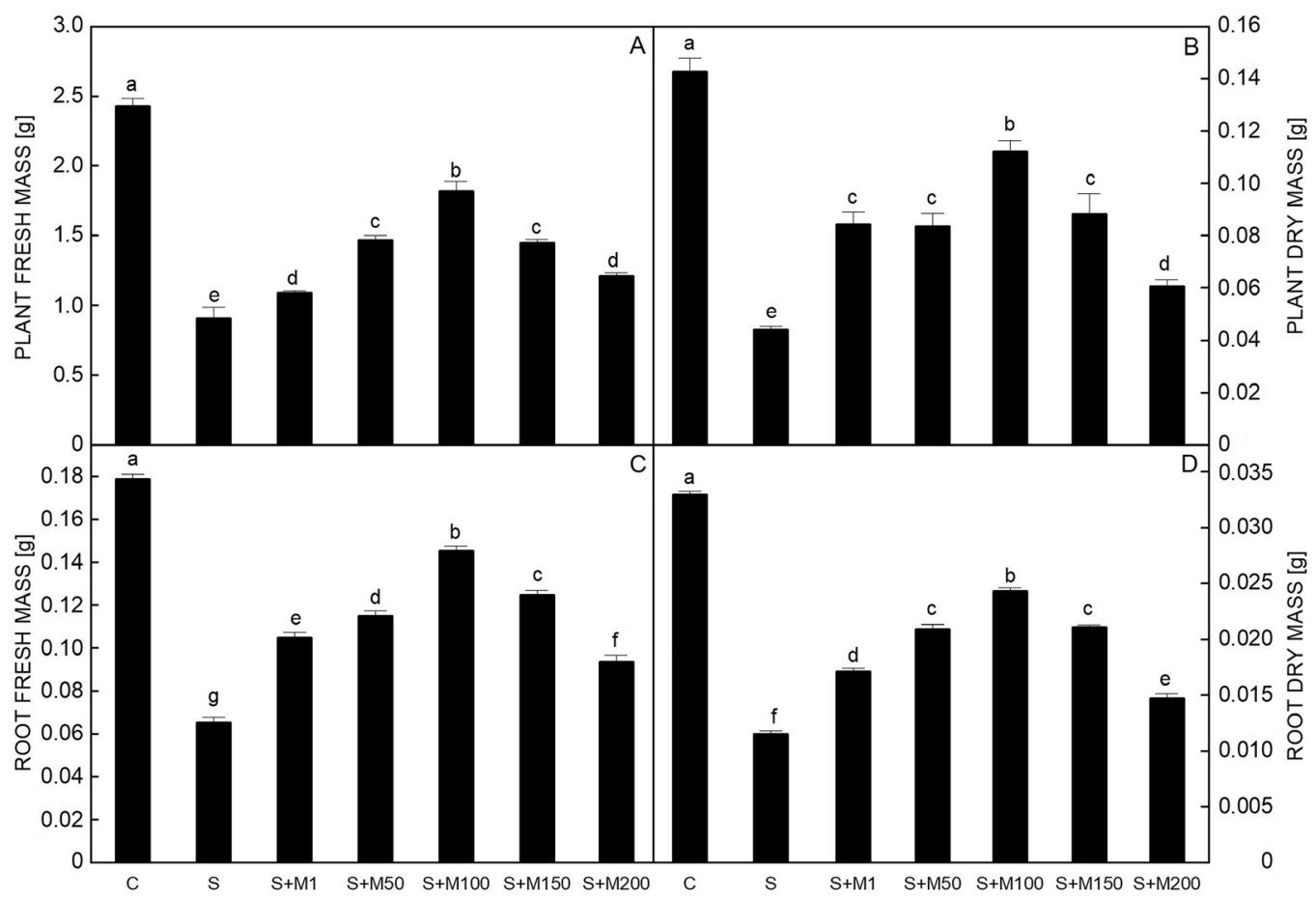

Fig. 2. Influence of $\mathrm{NaCl}$ alone or in combinations with various concentration of melatonin on plant fresh mass $(A)$, plant dry mass $(B)$, root fresh mass $(C)$, and root dry mass $(D)$, in tomato seedlings. C - control, $\mathrm{S}-150 \mathrm{mM} \mathrm{NaCl}, \mathrm{S}+\mathrm{M} 1-150 \mathrm{mM} \mathrm{NaCl}+1 \mu \mathrm{M}$ melatonin, S+M50 - $150 \mathrm{mM} \mathrm{NaCl}+50 \mu \mathrm{M}$ melatonin, S+M100 - $150 \mathrm{mM} \mathrm{NaCl}+100 \mu \mathrm{M}$ melatonin, S+M150 - $150 \mathrm{mM} \mathrm{NaCl}+$ $150 \mu \mathrm{M}$ melatonin, $\mathrm{S}+\mathrm{M} 200-150 \mathrm{mM} \mathrm{NaCl}+200 \mu \mathrm{M}$ melatonin. Means $\pm \mathrm{SEs}, n=3$, significant differences are marked by different lowercase letters (at $P<0.05$ ) according to Duncan's multiple range test.

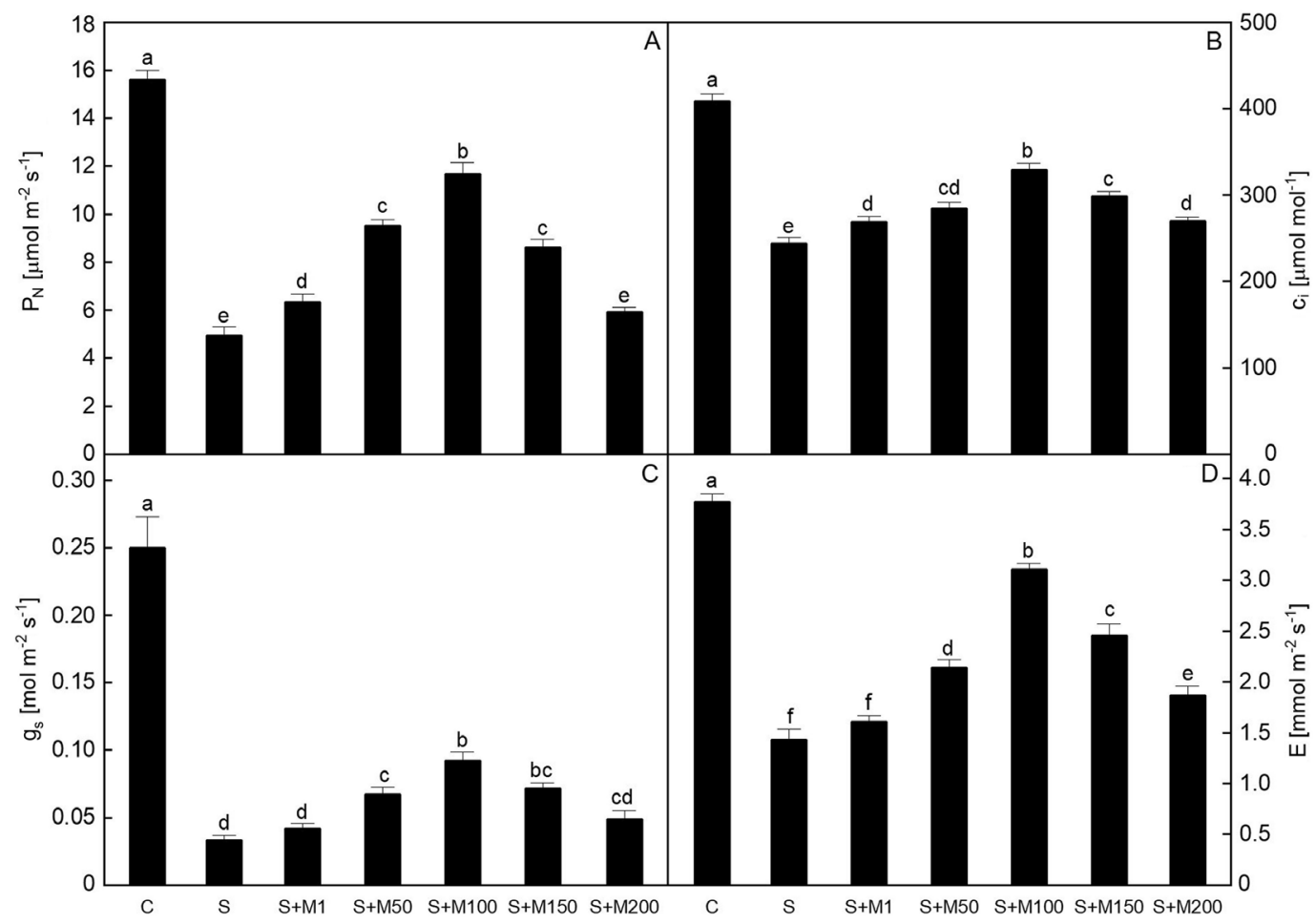

Fig. 3. Influence of $\mathrm{NaCl}$ alone or in combination with various concentrations of melatonin on $A$ - net photosynthetic rate $\left(\mathrm{P}_{\mathrm{N}}\right)$; $B$ - intercellular $\mathrm{CO}_{2}$ concentration $\left(\mathrm{c}_{\mathrm{i}}\right) ; C$ - stomatal conductance $\left(\mathrm{g}_{\mathrm{s}}\right) ; D$ - transpiration rate $(E)$ in tomato seedlings. C - control, $\mathrm{S}-150 \mathrm{mM} \mathrm{NaCl}, \mathrm{S}+\mathrm{M} 1-150 \mathrm{mM} \mathrm{NaCl}+1 \mu \mathrm{M}$ melatonin, $\mathrm{S}+\mathrm{M} 50-150 \mathrm{mM} \mathrm{NaCl}+50 \mu \mathrm{M}$ melatonin, $\mathrm{S}+\mathrm{M} 100-150 \mathrm{mM} \mathrm{NaCl}+$ $100 \mu \mathrm{M}$ melatonin, $\mathrm{S}+\mathrm{M} 150-150 \mathrm{mM} \mathrm{NaCl}+150 \mu \mathrm{M}$ melatonin, $\mathrm{S}+\mathrm{M} 200-150 \mathrm{mM} \mathrm{NaCl}+200 \mu \mathrm{M}$ melatonin. Means $\pm \mathrm{SEs}, n=3$, significant differences are marked by different lowercase letters (at $P<0.05$ ) according to Duncan's multiple range test. 
surface area, root tips and root forks showed a noticeable reduction after $\mathrm{NaCl}$ application (Fig. 5). Interestingly, these root growth parameters showed maximum at $100 \mu \mathrm{M}$ melatonin The tomato leaves exposed to $\mathrm{NaCl}$ stress showed increased $\mathrm{O}_{2}{ }^{--}$generation and $\mathrm{H}_{2} \mathrm{O}_{2}$ content, relative to the control plants. However, $\mathrm{NaCl}$-induced accumulation of $\mathrm{H}_{2} \mathrm{O}_{2}$ and $\mathrm{O}_{2}{ }^{--}$were significantly reduced by the application of melatonin (from 50 to $150 \mu \mathrm{M}$ ) and $100 \mu \mathrm{M}$ treatment showed a maximum removal efficiency of $\mathrm{O}_{2}{ }^{--}$and $\mathrm{H}_{2} \mathrm{O}_{2}$ (Fig. $6 A, B$ ). Similarly, compared to the control, a significant increase in both EL and MDA content was observed in $\mathrm{NaCl}$ stressed tomato leaves, and a melatonin-pretreatment at 50,100, and $150 \mu \mathrm{M}$ doses attenuated these increases (Fig. 6C,D).

The impact of salt stress and melatonin application on the activity of antioxidant enzymes was also investigated. The activities of SOD, GR, CAT, and APX showed significant enhancement under salinity stress. When compared with salinity stress alone, activities of all four antioxidant enzymes were further enhanced with pretreatment of melatonin, except at $200 \mu \mathrm{M}$ concentration, and under an application of $100 \mu \mathrm{M}$ melatonin, the highest activity of all antioxidant enzymes was detected (Fig. 7).

The hierarchical cluster analysis (complete clustering algorithm) was carried out for a total of 27 dependent variables. The dendrogram illustrated that all the traits could be grouped into four major clusters (Fig. 1 Suppl.).

\section{Discussion}

Many abiotic stresses limit plant growth and biomass production and salinity is one of them as explained by Gómez-Pando et al. (2010) and Jampeetong and Brix (2009). The current study highlights the significant decline in almost all of the growth parameters of plants under salt stress but this decline was significantly alleviated by the exogenous melatonin, which has been proved as a plant growth regulator (Zhang et al. 2013). Ke et al. (2018), Li et al. (2019c), Yin et al. (2019), Zafar et al. (2019), and Zhang et al. (2020) showed that leaf senescence can be delayed by application of melatonin and also plant resistance against cold, drought, salt, and many other abiotic stresses can be enhanced. Results of the current study indicated that growth and biomass production could be effectively increased by $100 \mu \mathrm{M}$ melatonin (Figs. 1 and 2). In rapeseed seedlings, Liu et al. (2018) also confirmed alleviation of salt-induced growth (root dry mass, root fresh mass, plant dry mass, and plant fresh mass) inhibition by melatonin application. Li et al. (2012) and Wang et al. (2016a) also justify such a beneficial role of melatonin as a plant growth regulator under salt stress. Thus our results confirmed the alleviation of salt stress-inhibited plant growth with the help of exogenous melatonin.

One of the basic physiological processes is photo-

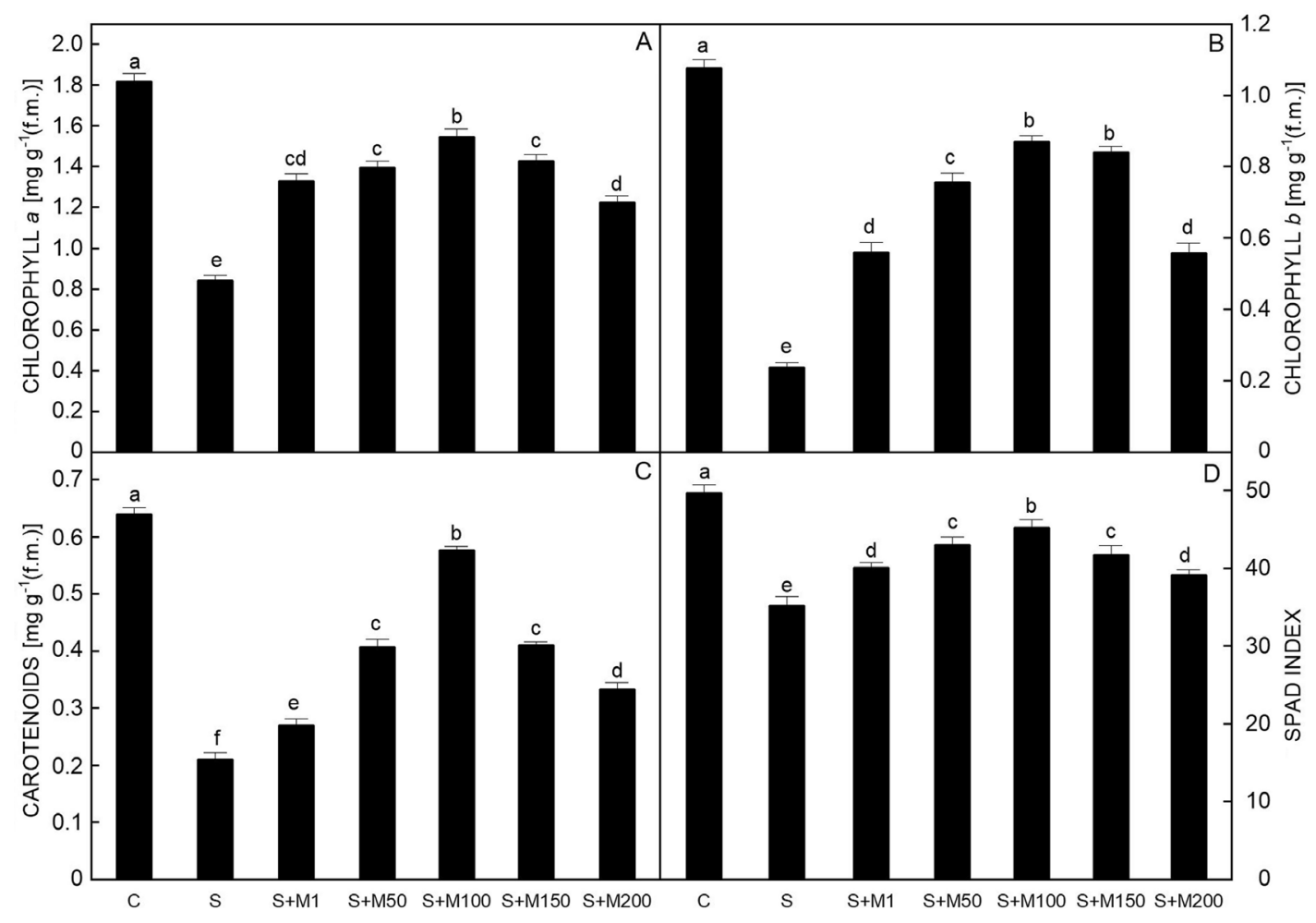

Fig. 4. Influence of $\mathrm{NaCl}$ alone or in combination with various concentrations of melatonin on chlorophyll $a(A)$, chlorophyll $b(B)$, carotenoids $(C)$, and SPAD index $(D)$, in tomato seedlings. C - control, $\mathrm{S}-150 \mathrm{mM} \mathrm{NaCl}, \mathrm{S}+\mathrm{M} 1-150 \mathrm{mM} \mathrm{NaCl}+1 \mu \mathrm{M}$ melatonin, $\mathrm{S}+\mathrm{M} 50-150 \mathrm{mM} \mathrm{NaCl}+50 \mu \mathrm{M}$ melatonin, $\mathrm{S}+\mathrm{M} 100-150 \mathrm{mM} \mathrm{NaCl}+100 \mu \mathrm{M}$ melatonin, $\mathrm{S}+\mathrm{M} 150-150 \mathrm{mM} \mathrm{NaCl}+150 \mu \mathrm{M}$ melatonin, $\mathrm{S}+\mathrm{M} 200-150 \mathrm{mM} \mathrm{NaCl}+200 \mu \mathrm{M}$ melatonin. Means $\pm \mathrm{SEs}, n=3$, significant differences are marked by different lowercase letters (at $P<0.05$ ) according to Duncan's multiple range test. 
synthesis. As reported by Parida and Das (2005) and Takahashi and Murata (2008), rate of saccharide production is reduced under salinity. Usually, higher content of chlorophyll result in higher photosynthesis and hence better plant performance. In the current study, it is revealed that $\mathrm{NaCl}$ application decreased the SPAD index, net photosynthetic rate, transpiration rate, stomatal conductance, and intercellular $\mathrm{CO}_{2}$ concentration in tomato leaves (Figs. $3 A-D$ and $4 D$ ) and these characteristics were improved by pretreatment with melatonin. Liang et al. (2015) revealed that in rice seedlings, melatonin delays senescence and improves chlorophyll content by direct reduction of ROS and enhanced antioxidant capacity. The protective role of melatonin pretreatment has been proved under salinity in many plants. Many studies reported that photosynthesis and chlorophyll content were improved in tomato seedlings (Zhou et al. 2016, Yin et al. 2019), watermelon seedling ( $\mathrm{Li}$ et al. 2017a), lettuce seedling (Yan et al. 2016), and cucumber seedling (Wang et al. 2016a, Zhang et al. 2020). Under drought, it has been reported by Liu et al. (2015a) that antioxidant capacity and photosynthesis of tomato seedlings are enhanced by melatonin treatment. Similarly, Hasan et al. (2015) reported melatonin induced-improvement of tolerance of tomato seedlings to Cd stress, by enhancement of plant biomass and hence photosynthesis. Nawaz et al. (2018) revealed that seedlings pretreated with melatonin showed increased SPAD index, photosynthetic assimilation, and plant growth under vanadium toxicity. Similarly, under salt stress, tolerance is enhanced by biosynthesis of melatonin in chloroplasts (Zheng et al. 2017). It was also shown by Jiang et al. (2016) that in maize under salt stress, chlorophyll content and $\mathrm{P}_{\mathrm{N}}$ were reduced less by $1 \mu \mathrm{M}$ melatonin application. In our study, for improving

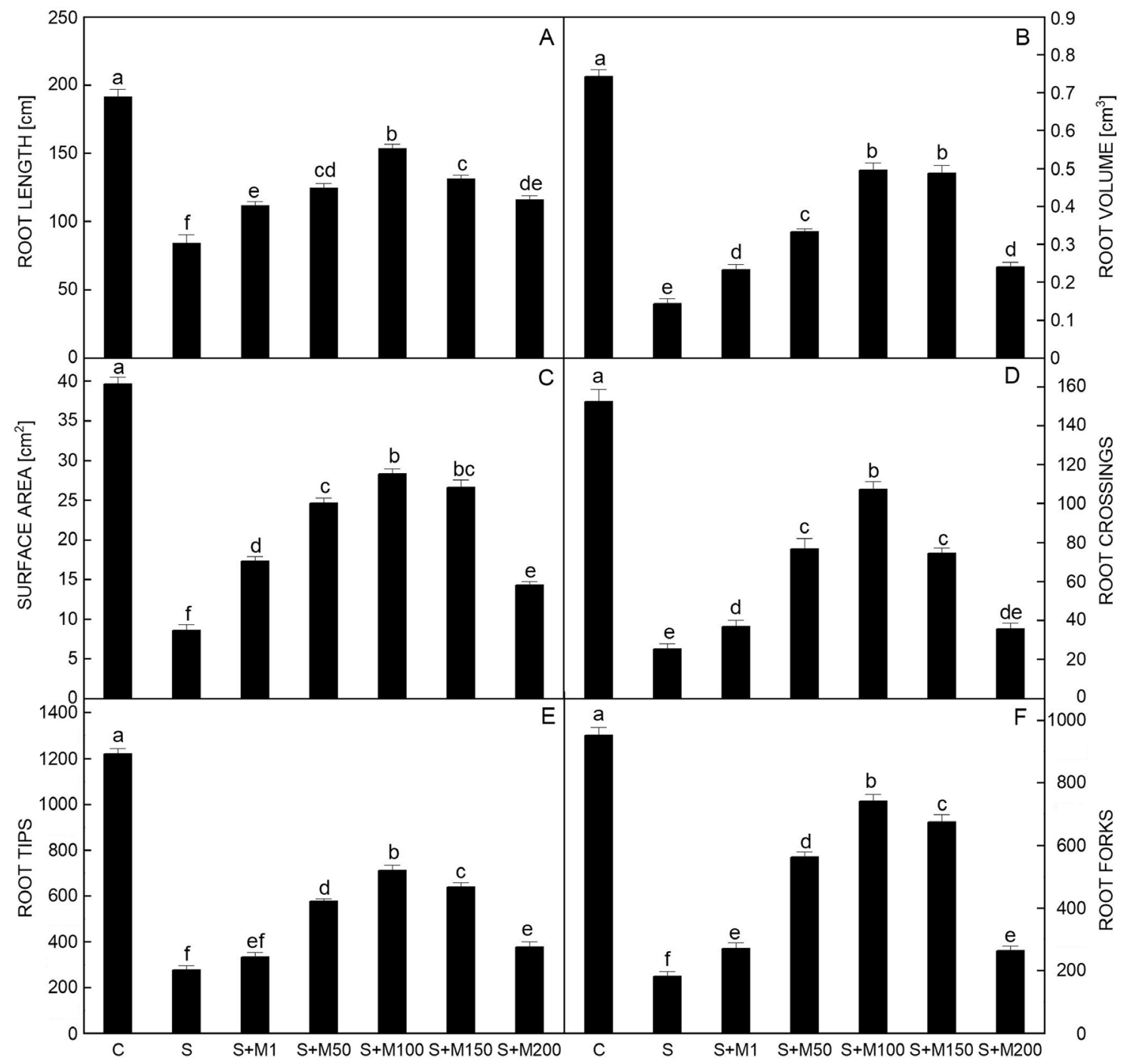

Fig. 5. Influence $\mathrm{NaCl}$ alone or in combination with various concentrations of melatonin on root length $(A)$, root volume $(B)$, surface area $(C)$, root crossings $(D)$, root tips $(E)$, and root forks $(F)$, in tomato seedlings. C - control, $\mathrm{S}-150 \mathrm{mM} \mathrm{NaCl}, \mathrm{S}+\mathrm{M} 1-150 \mathrm{mM} \mathrm{NaCl}$ $+1 \mu \mathrm{M}$ melatonin, $\mathrm{S}+\mathrm{M} 50-150 \mathrm{mM} \mathrm{NaCl}+50 \mu \mathrm{M}$ melatonin, $\mathrm{S}+\mathrm{M} 100-150 \mathrm{mM} \mathrm{NaCl}+100 \mu \mathrm{M}$ melatonin, $\mathrm{S}+\mathrm{M} 150-150 \mathrm{mM}$ $\mathrm{NaCl}+150 \mu \mathrm{M}$ melatonin, $\mathrm{S}+\mathrm{M} 200-150 \mathrm{mM} \mathrm{NaCl}+200 \mu \mathrm{M}$ melatonin. Means $\pm \mathrm{SEs}, n=3$, significant differences are marked by different lowercase letters (at $P<0.05$ ) according to Duncan's multiple range test. 
photosynthesis under salinity stress, $100 \mu \mathrm{M}$ melatonin was found as the most effective one as compared to 1 or $200 \mu \mathrm{M}$ concentrations.

Chlorophyll $a$, chlorophyll $b$, and carotenoids are the primary photosynthetic pigments which are decreased by salt stress, possibly due to an accumulation of sodium ions that may cause changes in fine structure of chloroplast (Kao et al. 2003, Siddiqui et al. 2008). Xie et al. (2018) and Yin et al. (2019) demonstrated that the accumulation of chlorophylls and carotenoid is enhanced significantly by melatonin pretreatment. The results are in line with the study of Zhang et al. (2017b) on melon showing that exogenous melatonin maintains chlorophyll stability under cold stress. Moreover, Wei et al. (2015), Shi et al. (2015,) and Chen et al. (2018) determined that under different environmental stresses, the decrease in photosynthetic pigments might be alleviated by melatonin treatment. Our data also confirm these results. It was revealed a higher content of photosynthetic pigments under salinity stress after application of melatonin compared with salt treatment alone (Fig. 4A-C).

The significant factors contributing to the efficiency of nutrients uptake in plants are root size and root architecture (O'Toole and Bland 1987, Fitter et al. 1991, 2008, Cruz et al. 2004, Postma and Lynch 2012). Meister et al. (2014), Rogers and Benfey (2015), Wissuwa et al. (2016) and Meng et al. (2019) suggested that plant growth can be improved by the enhancement of nutrient uptake and utilization efficiency due to modifications in root architecture. Root architecture can be changed in response to $\mathrm{NaCl}$ toxicity, as mentioned by Van Hoorn et al. (2001), Flores et al. (2002), Mahajan and Tuteja (2005), and Shafi et al. (2010). Adverse effects of $\mathrm{NaCl}$ limiting root growth in tomato plants are reported by Li et al. (2019b). Under salt stress, root growth is reduced from many possible reasons. Soils with high salt content account for a great decline in surface area and length of roots, followed by reduced uptake of nutrients and water. The current study showed the adverse effect of $\mathrm{NaCl}$ application on tomato root growth, root volume, total root length, root surface area, and root tips and these root traits were improved with melatonin pretreatment (Fig. 5), and thus melatonin pretreatment contributed to better growth of whole seedlings. Arnao and Hernández Ruiz (2007) reported that new root development and stimulation of root growth indicate the physiological roles of melatonin. Wang et al. (2016b) also reported that in Arabidopsis, root structure and morphology is affected by melatonin. Moreover, the relationship between the application of melatonin and root growth has been noted in tomato (Liu et al. 2015a), cucumber (Zhang et al. 2013, 2017a), watermelon (Nawaz et al. 2018), and rice (Han et al. 2017, Liang et al. 2017) in abiotic stress.

According to Wilhelm and Selmar (2011), the photosynthesis efficiency gets reduced by $\mathrm{NaCl}$ stress, thus resulting in obstruction of electron transfer and

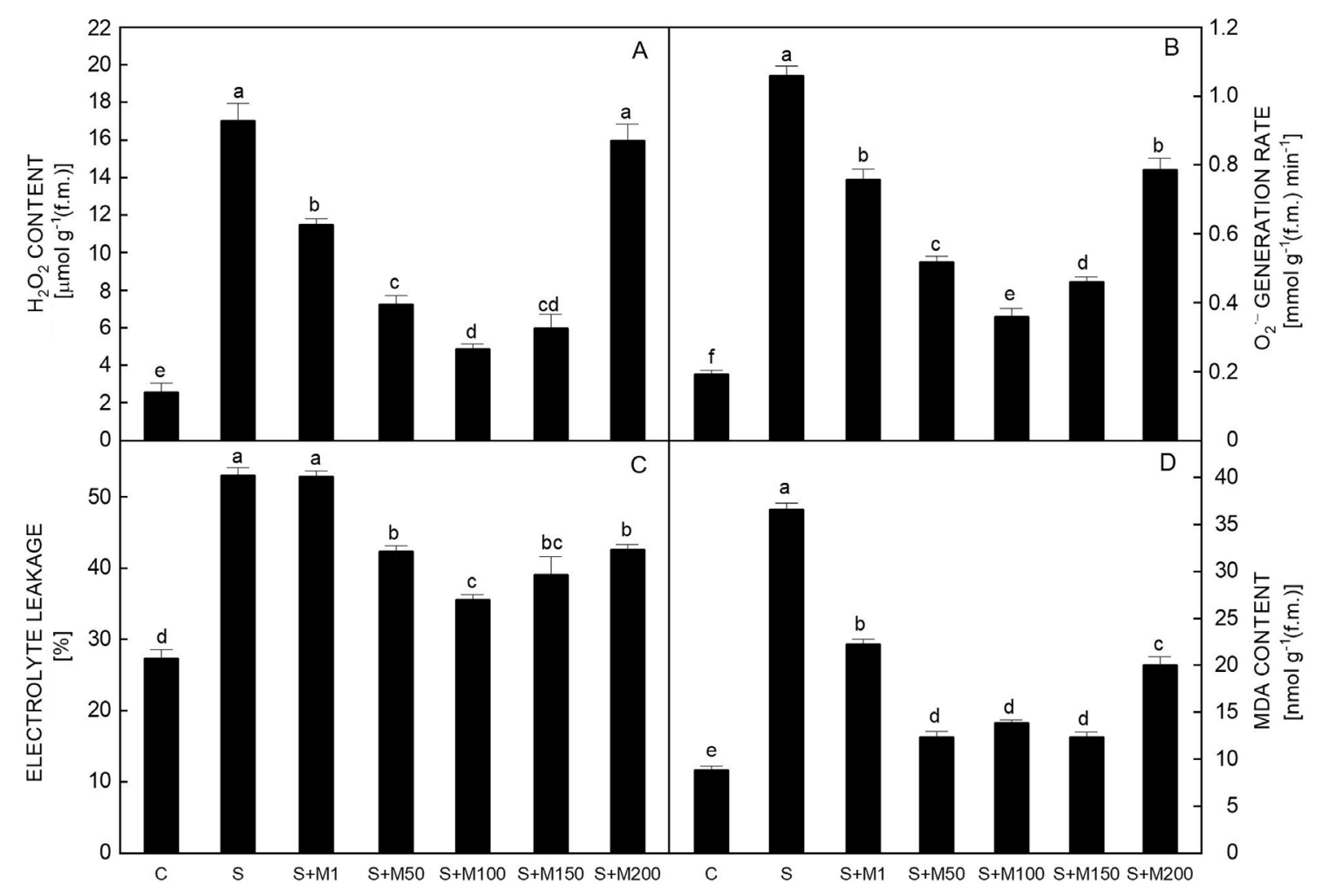

Fig. 6. Influence of $\mathrm{NaCl}$ alone or in combination with various concentrations of melatonin on hydrogen peroxide $\left(\mathrm{H}_{2} \mathrm{O}_{2}\right)$ content $(A), \mathrm{O}_{2}{ }^{--}$generation $(B)$, electrolyte leakage $(C)$, and malondialdehyde (MDA) content $(D)$, in tomato seedlings. $\mathrm{C}-$ control, $\mathrm{S}-150 \mathrm{mM} \mathrm{NaCl}, \mathrm{S}+\mathrm{M} 1-150 \mathrm{mM} \mathrm{NaCl}+1 \mu \mathrm{M}$ melatonin, S+M50 - $150 \mathrm{mM} \mathrm{NaCl}+50 \mu \mathrm{M}$ melatonin, $\mathrm{S}+\mathrm{M} 100-150 \mathrm{mM} \mathrm{NaCl}+$ $100 \mu \mathrm{M}$ melatonin, $\mathrm{S}+\mathrm{M} 150-150 \mathrm{mM} \mathrm{NaCl}+150 \mu \mathrm{M}$ melatonin, $\mathrm{S}+\mathrm{M} 200-150 \mathrm{mM} \mathrm{NaCl}+200 \mu \mathrm{M}$ melatonin. Means $\pm \mathrm{SEs}, n=3$, significant differences are marked by different by lowercase letters (at $P<0.05$ ) according to Duncan's multiple range test. 
excess radiation energy accumulation leading to ROS accumulation. Zhang et al. (2012b) further mentioned that peroxidation of lipids caused by excess ROS increases the permeability of cell membranes and destruction of their functions. Our results show that the elevations of EL and MDA were consistent with the accumulation of $\mathrm{H}_{2} \mathrm{O}_{2}$ and $\mathrm{O}_{2}{ }^{-}$induced by salinity stress (Fig. 6). Still, this phenomenon can be suppressed by melatonin application. These findings are in line with the conclusion of many other studies of plants under oxidative stress (Zhang et al. 2012c, Wang et al. 2013, Wei et al. 2015, Gao et al. 2019, Yang et al. 2019a). Li et al. (2012), Zhang et al. (2014), and Zhao et al. (2018) reported a decrease in NaCl stressinduced oxidative damage by exogenous melatonin. The accumulation of $\mathrm{H}_{2} \mathrm{O}_{2}$ and $\mathrm{O}_{2}{ }^{--}$leads to the peroxidation of lipids, which ultimately results in membrane damage and electrolyte leakage (Sairam and Srivastava 2002, Khalid et al. 2014, Siddiqui et al. 2019). In abiotic stress, the integrity of the membrane can be assessed by several indicators; one of these is electrolyte leakage. The protective effect of melatonin in salinity-induced membrane damage is suggested by the reduction of MDA, $\mathrm{H}_{2} \mathrm{O}_{2}, \mathrm{O}_{2}{ }^{--}$, and electrolyte leakage. MDA content and electrolyte leakage caused by salt stress can be significantly be reduced by $1 \mu \mathrm{M}$ melatonin (Jiang et al. 2016). The MDA content and relative conductivity can be decreased by melatonin pretreatment in tomato seedling (Hasan et al. 2015) and cucumber seedling (Zhang et al. 2020).

For reducing oxidative stress in plants and scavenging excessive ROS, there exists a defense system containing antioxidant enzymes and other antioxidants. According to Manchester et al. (2015), plants can be protected from oxidative stress by melatonin, which directly enhances the activity of antioxidative enzymes and so scavenging free radicals and excess ROS. For instance, salt stressinduced oxidative stress can significantly be alleviated by melatonin in tomato (Siddiqui et al. 2019, Yin el al. 2019) and in cucumber (Wang et al. 2016a, Zhang et al. 2020), cadmium-induced oxidative stress in rice (Byeon et al. 2015) and paraquat-induced oxidative stress in Arabidopsis thaliana (Weeda et al. 2014). Similarly, as mentioned by Li et al. (2017b), under low-temperature stress, the content of ROS can be reduced and the activity of an antioxidant enzyme can be enhanced by melatonin in wheat seedlings. The current study also demonstrated that in tomato seedlings under salinity stress, production of reactive oxygen species was reduced and the activity of the antioxidant enzyme was enhanced by exogenous melatonin (Fig. 7). Melatonin is also known as a broadspectrum antioxidant (Arnao and Hernández-Ruiz 2014), a potential antioxidant (Manchester et al. 2015, Reiter et al. 2016, Yang et al. 2019a), and a free radical scavenger

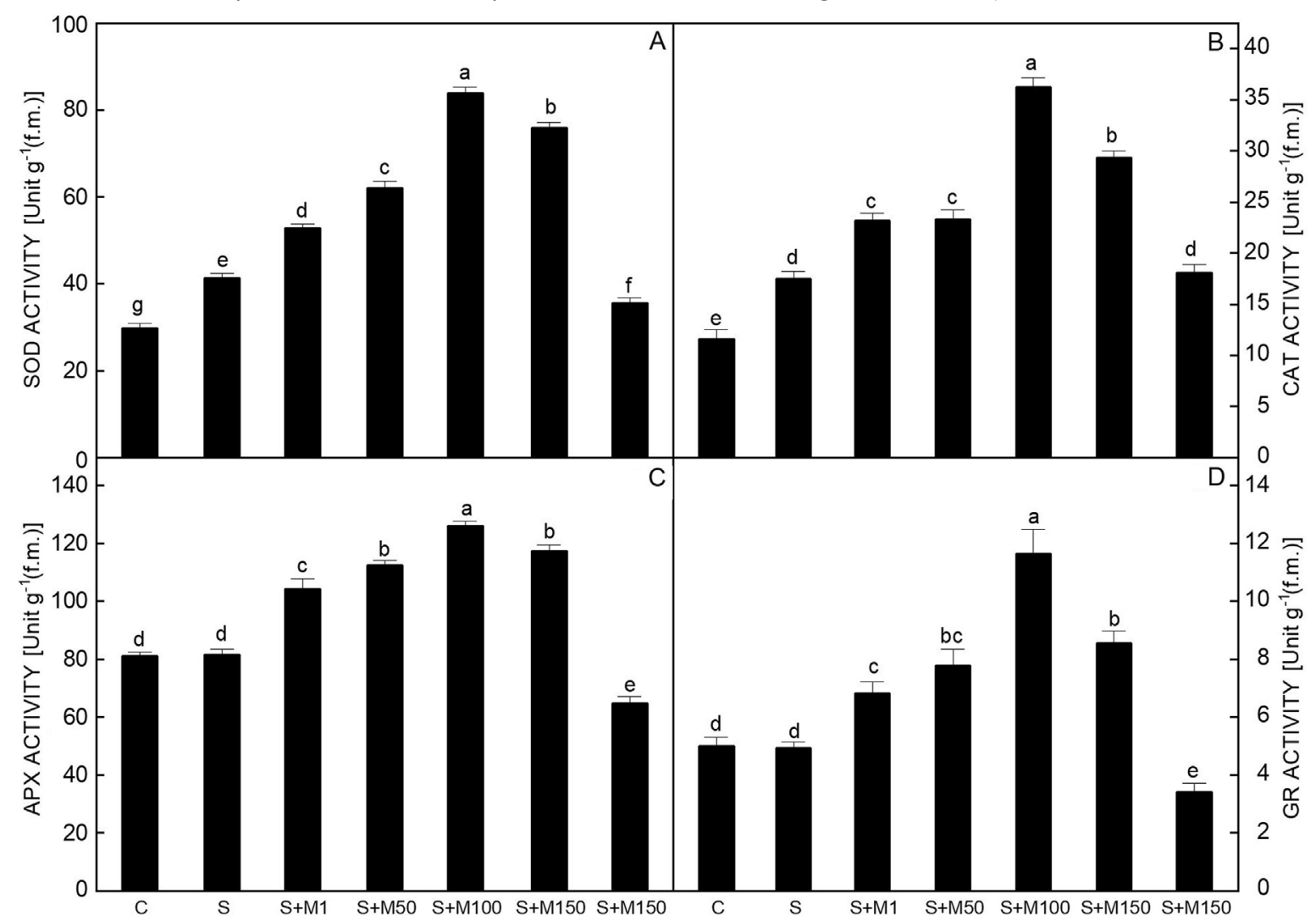

Fig. 7. Influence of $\mathrm{NaCl}$ alone or in combination with various concentrations of melatonin on superoxide dismutase (SOD) activity $(A)$, catalase (CAT) activity $(B)$, ascorbate peroxidase (APX) activity $(C)$, and glutathione reductase (GR) activity $(D)$, in tomato seedlings. $\mathrm{C}$ - control, $\mathrm{S}-150 \mathrm{mM} \mathrm{NaCl}, \mathrm{S}+\mathrm{M} 1-150 \mathrm{mM} \mathrm{NaCl}+1 \mu \mathrm{M}$ melatonin, $\mathrm{S}+\mathrm{M} 50-150 \mathrm{mM} \mathrm{NaCl}+50 \mu \mathrm{M}$ melatonin, $\mathrm{S}+\mathrm{M} 100-150 \mathrm{mM}$ $\mathrm{NaCl}+100 \mu \mathrm{M}$ melatonin, $\mathrm{S}+\mathrm{M} 150-150 \mathrm{mM} \mathrm{NaCl}+150 \mu \mathrm{M}$ melatonin, $\mathrm{S}+\mathrm{M} 200-150 \mathrm{mM} \mathrm{NaCl}+200 \mu \mathrm{M}$ melatonin. Means $\pm \mathrm{SEs}, n=3$, significant differences are marked by different by lowercase letters (at $P<0.05$ ) according to Duncan's multiple range test. 
(Reiter et al. 2007). The theory of melatonin role as a plant protectant under any stress by reducing stress-induced oxidative stress at a cellular level is supported by these findings.

The significant role of melatonin in the defense system of plant is proved by many studies, and exogenous melatonin can alleviate any stress-induced oxidative stress. Melatonin is a pleiotropic molecule acting as an amphiphilic agent; thus it passes quickly through cell membrane into subcellular compartments. Exogenous melatonin can be employed in agriculture or in horticulture for ameliorating decline of the stress-induced damage in crops. In-depth and excessive research is still needed on the mechanism of action of melatonin, for better development of its application potential.

The dendrogram analysis classified all studied parameters into four major groups (Fig. 1 Suppl.). The possible mode of action for alleviation of salt stress in tomato seedlings pretreated with melatonin is summarized in (Fig. 2 Suppl.). It is thus concluded that melatonin acts as a cost-effective, stable and environmental friendly molecule which is easily available and can protect plants against environmental stresses such as salt stress, by ameliorating the root growth and biomass production, enhancing photosynthesis and antioxidant enzymes activity, and minimizing oxidative stress.

\section{Conclusions}

The current study found out that plant growth was severely reduced by $\mathrm{NaCl}$ application. In a dose-dependent manner, melatonin pretreatment of tomato seedlings significantly enhanced stress tolerance. Melatonin pretreatment improved the growth and biomass production, enhanced the activity of antioxidant enzymes, reduced $\mathrm{H}_{2} \mathrm{O}_{2}, \mathrm{O}_{2}{ }^{--}$, $\mathrm{EL}$, and MDA content, promote root growth, enhanced photosynthetic assimilation and photosynthetic pigments content. Under salinity stress, such events enhanced salinity tolerance of tomato seedlings with melatonin pretreatment. It is hoped that in agriculture, a positive influence of melatonin on salt tolerance can open novel opportunities for its use. The role of melatonin in root growth promotion is widely reported, but further investigation regarding nutrient uptake due to melatonin is still needed; as there is little evidence regarding the role of melatonin in nutrient uptake and transport.

\section{References}

Aebi, H.: Catalase in vitro. - Methods Enzymol. 105: 121-126, 1984.

Afreen, F., Zobayed, S.M.A., Kozai, T.: Melatonin in Glycyrrhiza uralensis: response of plant roots to spectral quality of light and UV-B radiation. - J. Pineal Res. 41: 108-115, 2006.

Aguilera, Y., Herrera, T., Benitez, V., Arribas, S.M., López de Pablo, A.L., Esteban, R.M., Martín-Cabrejas, M.A.: Estimation of scavenging capacity of melatonin and other antioxidants: contribution and evaluation in germinated seeds.
- Food Chem. 170: 203-211, 2015.

Ahuja, I.: Plant molecular stress responses face climate change. Trends Plant Sci. 15: 664-674, 2010.

Arnao, M.B., Hernández Ruiz, J.: Melatonin promotes adventitious and lateral root regeneration in etiolated hypocotyls of Lupinus albus L. - J. Pineal Res. 42: 147-152, 2007.

Arnao, M.B., Hernández-Ruiz, J.: Functions of melatonin in plants: a review. - J. Pineal Res. 59: 133-150, 2015.

Arnao, M.B., Hernández-Ruiz, J.: Melatonin: plant growth regulator and/or biostimulator during stress? - Trends Plant Sci. 19: 789-797, 2014.

Bajwa, V.S., Shukla, M.R., Sherif, S.M., Murch, S.J., Saxena, P.K.: Role of melatonin in alleviating cold stress in an Arabidopsis thaliana. - J. Pineal Res. 56: 238-245, 2014.

Beyer, W.F., Fridovich, I.: Assaying for superoxide-dismutase activity - some large consequences of minor changes in conditions. - Anal. Biochem. 161: 559-566, 1987.

Byeon, Y., Lee, H.Y., Hwang, O.J., Lee, H.J., Lee, K., Back, K.: Coordinated regulation of melatonin synthesis and degradation genes in rice leaves in response to cadmium treatment. - J. Pineal Res. 58: 470-478, 2015.

Cao, Q., Li, G., Cui, Z., Yang, F., Jiang, X., Diallo, L., Kong, F.: Seed priming with melatonin improves the seed germination of waxy maize under chilling stress via promoting the antioxidant system and starch metabolism. - Sci. Rep. 9: 1-12, 2019.

Chen, Y. E., Mao, J.J., Sun, L.Q., Huang, B., Ding, C.B., Gu, Y., Yuan, M.: Exogenous melatonin enhances salt stress tolerance in maize seedlings by improving antioxidant and photosynthetic capacity. - Physiol. Plant. 164: 349-363, 2018.

Cruz, C., Green, J.J., Watson, C.A., Wilson, F., Martins-Loucao, M.A.: Functional aspects of root architecture and mycorrhizal inoculation with respect to nutrient uptake capacity. Mycorrhiza 14: 177-184, 2004.

Dubbels, R., Reiter, R.J., Klenke, E.: Melatonin in edible plants identified by radioimmunoassay and by high performance liquid chromatography - mass spectrometry. - J. Pineal Res. 18: 28-31, 1995.

Elstner, E.F., Heupel, A.: Formation of hydrogen-peroxide by isolated cell-walls from horseradish (Armoracia-lapathifolia Gilib). - Planta 130: 175-180, 1976.

Fitter, A.H., Stickland, T.R., Harvey, M.L.: Wilson, G.W. Architectural analysis of plant root systems. 1. Architectural correlates of exploitation efficiency. - New Phytol. 118: 375382, 1991.

Fitter, A.H.: Characteristics and function of root systems. - In: Waisel, Y., Eshel, A., Kafkafi, U. (ed.): Plant Roots. - The Hidden Half. Pp. 3-25. Marcel Dekker, New York 2008.

Flores, P., Botella, M.A., Martinez, V., Cerda, A.: Response to salinity of tomato seedlings with a split root system: nitrate uptake and reduction. - J. Plant Nutr. 25: 177-87, 2002.

Foyer, C.H., Halliwell, B.: The presence of glutathione and glutathione reductase in chloroplasts: a proposed role in ascorbic acid metabolism. - Planta 133: 21-25, 1976.

Galano, A., Tan, D.X., Reiter, R.J.: Melatonin as a natural ally against oxidative stress: a physicochemical examination. - J. Pineal Res. 51: 1-16, 2011.

Gao, W., Feng, Z., Bai, Q., He, J., Wang, Y.: Melatonin-mediated regulation of growth and antioxidant capacity in salt-tolerant naked oat under salt stress. - Int. J. mol. Sci. 20: 1176, 2019.

Gómez-Pando, L.R., Álvarez-Castro, R., Eguiluz-de la Barra, A.: Effect of salt stress on peruvian germplasm of Chenopodium quinoa Willd.: a promising crop. - J. Agron. Crop Sci. 196: 391-396, 2010.

Han, Q.H., Huang, B., Ding, C.B., Zhang, Z.W., Chen, Y.E., Hu, 
C., Zhou, L.J., Huang, Y., Liao, J.Q., Yuan, S.: Yuan, M. Effects of melatonin on anti-oxidative systems and photosystem II in cold-stressed rice seedlings. - Front Plant Sci. 8: 1-14, 2017.

Han, Y., Wang, S., Zhao, N., Deng, S., Zhao, C., Li, N.: Exogenous abscisic acid alleviates cadmium toxicity by restricting $\mathrm{Cd}^{2+}$ influx in Populus euphratica cells. - J. Plant Growth Regul. 35: 827-837, 2016.

Hardeland, R., Cardinali, D.P.: Srinivasan, V. Melatonin a pleiotropic, orchestrating regulator molecule. - Prog. Neurobiol. 93: 350-384, 2011.

Hasan, M.K., Ahammed, G.J., Yin, L., Shi, K., Xia, X., Zhou, Y., Yu, J.: Zhou, J.: Melatonin mitigates cadmium phytotoxicity through modulation of phytochelatins biosynthesis, vacuolar sequestration, and antioxidant potential in Solanum lycopersicum L. - Front. Plant Sci. 6: 601, 2015.

Hasanuzzaman, M., Nahar, K., Fujita, M.: Ecophysiology and responses of plants under salt stress. - In: Ahmad, P, Azooz, M.M., Prasad, M.N.V. (ed.): Ecophysiology and Responses of Plants under Salt Stress. Pp. 25-87. Springer, New York 2013.

Hattori, A., Migitaka, H., Iigo, M.: Identification of melatonin in plants and its effects on plasma melatonin levels and binding to melatonin receptors in vertebrates. - Biochem. mol. Biol Int. 35: 627-634, 1995.

Heath, R.L., Packer, L.: Photoperoxidation in isolated chloroplasts. I. Kinetics and stoichiometry of fatty acid peroxidation. - Arch. Biochem. Biophys. 125: 189-198, 1968.

Hernandez-Ruiz, J., Cano, A., Arnao, M.B.: Melatonin acts as a growth-stimulating compound in some monocot species. - J. Pineal Res. 39: 137-142, 2005.

Jahan, M.S., Shu, S., Wang, Y., Chen, Z., He, M., Tao, M., Guo, S.: Melatonin alleviates heat-induced damage of tomato seedlings by balancing redox homeostasis and modulating polyamine and nitric oxide biosynthesis. - BMC Plant Biol. 19: 1-16, 2019.

Jampeetong, A., Brix, H.: Effects of $\mathrm{NaCl}$ salinity on growth, morphology, photosynthesis and proline accumulation of Salvinia natans. - Aquat. Bot. 91: 181-186, 2009.

Jiang, C., Cui, Q., Feng, K., Xu, D., Li, C., Zheng, Q.: Melatonin improves antioxidant capacity and ion homeostasis and enhances salt tolerance in maize seedlings. - Acta Physiol. Plant. 38: 1-9, 2016.

Jiang, C., Zu, C., Lu, D., Zheng, Q., Shen, J.: Wang, H. Effect of exogenous selenium supply on photosynthesis, $\mathrm{Na}^{+}$ accumulation and antioxidative capacity of maize (Zea mays L.) under salinity stress. - Sci. Rep. 7: 42039, 2017

Kao, W.Y., Tsai, T.T., Shih, C.N.: Photosynthetic gas exchange and chlorophyll $a$ fluorescence of three wild soybean species in response to $\mathrm{NaCl}$ treatments. - Photosynthetica 41: 415419, 2003.

Kaya, C., Okant, M., Ugurlar, F., Alyemeni, M.N., Ashraf, M., Ahmad, P.: Melatonin-mediated nitric oxide improves tolerance to cadmium toxicity by reducing oxidative stress in wheat plants. - Chemosphere 225: 627-638, 2019.

Kaya, C., Sönmez, O., Aydemir, S., Dikilitas, M.: Mitigation effects of glycinebetaine on oxidative stress and some key growth parameters of maize exposed to salt stress. - Turk. J. Agr. Forest. 37: 188-194, 2013

Ke, Q., Ye, J., Wang, B., Ren, J., Yin, L., Deng, X., Wang, S.: Melatonin mitigates salt stress in wheat seedlings by modulating polyamine metabolism. - Front. Plant Sci. 9: 914, 2018.

Khalid, A.M., Nasim, A.R., Abdulbasset, M.A.: Salicylic acidmediated alleviation of cadmium toxicity in maize leaves. - J. Plant Sci. 2: 276-281, 2014

Khan, M.S., Hemalatha, S.: Biochemical and molecular changes induced by salinity stress in Oryza sativa L. - Acta Physiol.
Plant. 38: 166-173, 2016.

Li, C., Wang, P., Wei, Z., Liang, D., Liu, C., Yin, L., Jia, D., Fu, M., Ma, F.: The mitigation effects of exogenous melatonin on salinity-induced stress in Malus hupehensis. - J. Pineal Res. 53: 298-306, 2012.

Li, H., Chang, J., Chen, H., Wang, Z., Gu, X., Wei, C., Zhang, Y., Ma, J., Yang, J., Zhang, X.: Exogenous melatonin confers salt stress tolerance to watermelon by improving photosynthesis and redox homeostasis. - Front. Plant Sci. 8: 295, 2017a.

Li, J., Zhao, C., Zhang, M., Yuan, F., Chen, M.: Exogenous melatonin improves seed germination in Limonium bicolor under salt stress. - Plant signal. Behav. 14: 1659705, 2019a.

Li, X., Brestic, M., Tan, D.X., Zivcak, M., Zhu, X., Liu, S., Song, F., Reiter, R.J., Liu, F.: Melatonin alleviates low PS I-limited carbon assimilation under elevated $\mathrm{CO}_{2}$ and enhances the cold tolerance of off spring in chlorophyll $b$-deficient mutant wheat. - J. Pineal Res. 64: 2017 b.

Li, Y., Niu, W., Cao, X., Wang, J., Zhang, M., Duan, X., Zhang, Z.: Effect of soil aeration on root morphology and photosynthetic characteristics of potted tomato plants (Solanum lycopersicum L.) at different $\mathrm{NaCl}$ salinity levels. - BMC Plant Biol. 19: $331,2019 \mathrm{~b}$

Li, Z., Pei, X., Yin, S., Lang, X., Zhao, X., Qu, G.Z.: Plant hormone treatments to alleviate the effects of salt stress on germination of Betula platyphylla seeds. - J. Forest. Res. 30: $779-787,2019 \mathrm{c}$

Liang, C., Li, A., Yu, H., Li, W., Liang, C., Guo, S., Zhang, R., Chu, C.: Melatonin regulates root architecture by modulating auxin response in rice. - Front. Plant Sci. 8: 134, 2017.

Liang, C., Zheng, G., Li, W., Wang, Y., Hu, B., Wang, H., Wu, H., Qian, Y., Zhu, X.G., Tan, D.X., Chen, S.Y., Chu, C.: Melatonin delays leaf senescence and enhances salt stress tolerance in rice. - J. Pineal Res. 59: 91-101, 2015.

Liang, D., Ni, Z., Xia, H., Xie, Y., Lv, X., Wang, J., Lin, L., Deng, Q., Luo, X.: Exogenous melatonin promotes biomass accumulation and photosynthesis of kiwifruit seedlings under drought stress. - Sci. Hort. 246: 34-43, 2019.

Lichtenhaler, K., Wellburn, A.R.: Determinations of total carotenoids and chlorophylls $a$ and $b$ of leaf extracts in different solvents. - Biochem. Soc. Trans. 11: 591- 592, 1983.

Liu, C.Y., Yan, M., Huang, X.B., Yuan, Z.H.: Effects of salt stress on growth and physiological characteristics of pomegranate (Punica granatum L.) cuttings. - Pak. J. Bot. 50: 457-464, 2018.

Liu, J., Wang, W., Wang, L., Sun, Y.: Exogenous melatonin improves seedling health index and drought tolerance in tomato. - Plant Growth Regul. 77: 317-326, 2015a.

Liu, N., Jin, Z., Wang, S., Gong, B., Wen, D., Wang, X., Wei, M., Shi, Q.: Sodic alkaline stress mitigation with exogenous melatonin involves reactive oxygen metabolism and ion homeostasis in tomato. - Sci. Hort. 181: 18-25, 2015 b.

Liu, X., Xia, H., Yuan, X., Lv, X., Liang, D.: Effects of exogenous melatonin on the physiological characteristics of kiwifruit hayward under salt stress. - Earth environ. Sci. 237: 052076, 2019.

Liu, Z., Cai, J.S., Li, J.J., Lu, G.Y., Li, C.S., Fu, G.P., Cheng, Y.: Exogenous application of a low concentration of melatonin enhances salt tolerance in rapeseed (Brassica napus L.) seedlings. - J. integr. Agr. 17: 328-335, 2018.

Mahajan, S., Tuteja, N.: Cold, salinity and drought stresses: an overview. - Arch. Biochem. Biophys. 444: 139-158, 2005.

Manchester, L.C., Coto-Montes, A., Boga, J.A., Andersen, L.P.H., Zhou, Z., Galano, A., Vriend, J., Tan, D.X., Reiter, R.J.: Melatonin: an ancient molecule that makes oxygen metabolically tolerable. - J. Pineal Res. 59: 403-419, 2015.

Meister, R., Rajani, M.S., Ruzicka, D., Schachtman, D.P.: 
Challenges of modifying root traits in crops for agriculture. Trends Plant Sci. 19: 779-788, 2014.

Meng, F., Xiang, D., Zhu, J., Li, Y., Mao, C.: Molecular mechanisms of root development in rice. - Rice 12: 1-10, 2019.

Nakano, Y., Asada, K.: Hydrogen-peroxide is scavenged by ascorbate-specific peroxidase in spinach-chloroplasts. - J. Plant Physiol. 22: 867-880, 1981.

Nawaz, M.A., Huang, Y., Bie, Z., Ahmed, W., Reiter, R.J., Niu, M., Hameed, S.: Melatonin: current status and future perspectives in plant science. - Front. Plant Sci. 6: 1230, 2016.

Nawaz, M.A., Jiao, Y., Chen, C., Shireen, F., Zheng, Z., Imtiaz, M., Bie, Z., Huang, Y.: Melatonin pretreatment improves vanadium stress tolerance of watermelon seedlings by reducing vanadium concentration in the leaves and regulating melatonin biosynthesis and antioxidant-related gene expression. - J. Plant Physiol. 220: 115-127, 2018.

O'Toole, J.C., Bland, W.L.: Genotypic variation in crop plant root systems. - Adv. Agron. 41: 91-145, 1987.

Parida, A.K., Das, A.B.: Salt tolerance and salinity effects on plants: a review. - Curr. Plant Sci. Biotechnol. Agr. 60: 324349, 2005 .

Park, S., Back, K.: Melatonin promotes seminal root elongation and root growth in transgenic rice after germination. - J. Pineal Res. 53: 385-389, 2012.

Peng, B., Xu, W., Shao, R.: Effects of salt stress on growth, photosynthetic pigment and osmotic regulatory substances of Salicornia salicornii seedlings from different habitats. - Mar. Pollut. Bull. 1: 63-72, 2017.

Postma, J.A., Lynch, J.P.: Complementarity in root architecture for nutrient uptake in ancient maize/bean and maize/bean/ squash polycultures. - Ann. Bot. 110: 521-534, 2012.

Reiter, R.J., Mayo, J.C., Tan, D.X., Sainz, R.M., AlatorreJimenez, M., Qin, L.: Melatonin as an antioxidant: under promises but over delivers. - J. Pineal Res. 61: 253-278, 2016.

Reiter, R.J., Tan, D.X., Galano, A.: Melatonin: exceeding expectations. - Physiology 29: 325-333, 2014.

Reiter, R.J., Tan, D.X., Terron M.P.: Melatonin and its metabolites: new findings regarding their production and their radical scavenging actions. - Acta biochim. 54: 1-9, 2007.

Rogers, E.D., Benfey, P.N.: Regulation of plant root system architecture: implications for crop advancement. - Curr. Opin. Biotechnol. 32: 93-98, 2015.

Ruiz-Lozano, J.M., Porcel, R., Azcon, R., Aroca, R.: Regulation by arbuscular mycorrhizae of the integrated physiological response to salinity in plants: new challenges in physiological and molecular studies. - J. exp. Bot. 63: 4033-4044, 2012.

Sairam, P.K., Srivastava, G.C.: Changes in antioxidant activity in sub-cellular fractions of tolerant and susceptible wheat genotypes in response to long term salt stress. - Plant Sci. 162: 897-904, 2002.

Shafi, M., Zhang, G., Bakht, J., Khan, M.A., Islam, U.E., Khan, M.D., Raziuddin, G.Z.: Effect of cadmium and salinity stresses on root morphology of wheat. - Pak. J. Bot 42: 274754,2010

Shi, H., Jiang, C., Ye, T., Tan, D., Reiter, R.J., Zhang, H., Liu, R., Chan, Z.: Comparative physiological, metabolomic, and transcriptomic analyses reveal mechanisms of improved abiotic stress resistance in bermudagrass Cynodon dactylon L. by exogenous melatonin. - J. integr Plant Biol. 66: 681694, 2015.

Siddiqui, M.H., Alamri, S., Al-Khaishany, M.Y., Khan, M.N., Al-Amri, A., Ali, H.M., Alsahli, A.A.: Exogenous melatonin counteracts $\mathrm{NaCl}$-induced damage by regulating the antioxidant system, proline and carbohydrates metabolism in tomato seedlings. - Int. J. mol Sci. 20: 353, 2019.
Siddiqui, M.H., Khan, M.N., Mohammad, F., Khan, M.M.A.: Role of nitrogen and gibberellin $\left(\mathrm{GA}_{3}\right)$ in the regulation of enzyme activities and in osmoprotectant accumulation in Brassica juncea L. under salt stress. - J. Agron. Crop Sci. 194: 214-224, 2008.

Takahashi, S., Murata, N.: How do environmental stresses accelerate photo inhibition? - Trends Plant Sci. 13: 178-182, 2008.

Uchendu, E.E., Shukla, M.R., Reed, B.M., Saxena, P.K.: Melatonin enhances the recovery of cryopreserved shoot tips of American elm (Ulmus americana L.). - J. Pineal Res. 55: 435-442, 2013.

Van Hoorn, J.W., Katerji, N., Hamdy, A., Mastrorilli, M.: Effect of salinity on yield and nitrogen uptake of four grain legumes and on biological nitrogen contribution from the soil. - Agr. Water Manage. 51: 87-98, 2001.

Velikova, V., Yordanov, I., Edreva, A.: Oxidative stress and some antioxidant systems in acid rain-treated bean plants protective role of exogenous polyamines. - Plant Sci. 151: 59-66, 2000.

Wang, L.Y., Liu, J.L., Wang, W.X., Sun, Y.: Exogenous melatonin improves growth and photosynthetic capacity of cucumber under salinity-induced stress. - Photosynthetica 54: 19-27, 2016a.

Wang, P., Sun, X., Li, C., Wei, Z., Liang, D., Ma, F.: Long-term exogenous application of melatonin delays drought-induced leaf senescence in apple. - J. Pineal Res. 54: 292-302, 2013.

Wang, Q., An, B., Wei, Y., Reiter, R.J., Shi, H., Luo, H., He, C.: Melatonin regulates root meristem by repressing auxin synthesis and polar auxin transport in Arabidopsis. - Front. Plant Sci. 7: 1882, 2016 b.

Weeda, S., Zhang, N., Zhao, X., Ndip, G., Guo, Y., Buck, G.A., Fu, C., Ren, S.: Arabidopsis transcriptome analysis reveals key roles of melatonin in plant defense systems. - PLoS ONE 9: e93462, 2014.

Wei, W., Li, Q.T., Chu, Y.N., Reiter, R.J., Yu, X.M., Zhu, D.H., Zhang, W.K., Ma, B., Lin, Q., Zhang, J.S., Chen, S.Y.: Melatonin enhances plant growth and abiotic stress tolerance in soybean plants. - J. exp. Bot. 66: 695-707, 2015.

Wei, Y., Hu, W., Wang, Q., Zeng, H., Li, X., Yan, Y., Reiter, R.J., He, C., Shi, H.: Identification, transcriptional and functional analysis of heat-shock protein $90 \mathrm{~s}$ in banana (Musa acuminata L.) highlight their novel role in melatonin-mediated plant response to Fusarium wilt. - J. Pineal Res. 62: e12367, 2017.

Wei, Z., Li, C., Gao, T., Zhang, Z., Liang, B., Lv, Z., Ma, F.: Melatonin increases the performance of Malus hupehensis after UV-B exposure. - Plant Physiol. Biochem. 139: 630-641, 2019.

Wilhelm, C., Selmar, D.: Energy dissipation is an essential mechanism to sustain the viability of plants: the physiological limits of improved photosynthesis. - J. Plant Physiol. 168: 7987, 2011.

Wissuwa, M., Kretzschmar, T., Rose, T.J.: From promise to application: root traits for enhanced nutrient capture in rice breeding. - J. exp. Bot. 67: 3605-3615, 2016.

Xie, Y., Sun, G., Liao, H., Tang, Y.: Effects of exogenous melatonin on photosynthetic physiology of lettuce seedlings under salt stress. - Advance eng. Res. 162: 81-84, 2018.

Yan, Z., Li, M., Tang, Y.: Effects of exogenous melatonin on photosynthetic characteristics of lettuce seedlings under $\mathrm{NaCl}$ stress. $-5^{\text {th }}$ International Conference on Energy and Environmental Protection (ICEEP 2016). - Pp. 365-369. Atlantis Press, Paris 2016.

Yang, H., Dai, L., Wei, Y., Deng, Z., Li, D.: Melatonin enhances salt stress tolerance in rubber tree (Hevea brasiliensis) seedlings. - Ind. Crops Prod. 145: 111990, 2019a. 
Yang, W.J., Du, Y.T., Zhou, Y.B., Chen, J., Xu, Z.S., Ma, Y.Z., Chen, M., Min, D.H.: Overexpression of TaCOMT improves melatonin production and enhances drought tolerance in transgenic Arabidopsis. - Int. J. mol. Sci. 20: 652, 2019 b.

Yang, Y., Chang, D., Wang, Y., Zhang, F.C.: Effects of exogenous $\mathrm{JA}$ and MeJA on seed germination and seeding physiological characteristics of Gossypium hirsutum under salt stress. - Seed 34: 8-18. 2015.

Yin, Z., Lu, J., Meng, S., Liu, Y., Mostafa, I., Qi, M., Li, T. Exogenous melatonin improves salt tolerance in tomato by regulating photosynthetic electron flux and the ascorbateglutathione cycle. - J. Plant Inter. 14: 453-463, 2019.

Zafar, S.A., Hasnain, Z.U., Anwar, S.U., Perveen, S.H., Iqbal, N.A., Noman, A., Ali, M.: Influence of melatonin on antioxidant defense system and yield of wheat (Triticum aestivum L.) genotypes under saline condition. - Pak. J. Bot. 51: 1987-1994, 2019.

Zhang, H.J., Zhang, N.A., Yang, R.C., Wang, L., Sun, Q.Q., Li, D.B., Cao, Y.Y., Weeda, S., Zhao, B., Ren, S., Guo, Y.D.: Melatonin promotes seed germination under high salinity by regulating antioxidant systems, $\mathrm{ABA}$ and $\mathrm{GA}_{4}$ interaction in cucumber (Cucumis sativus L.). - J. Pineal Res. 57: 269-279, 2014.

Zhang, H.J., Zhang, R., Sun, Y., Liu, Z., Jin, W., Sun, Y.: Effects of melatonin on seedling growth, mineral nutrition, and nitrogen metabolism in cucumber under nitrate stress. - J. Pineal Res. 62: e12403, 2017a.

Zhang, K., Cui, H., Cao, S. Yan, L., Li, M., Sun, Y.: Overexpression of $\mathrm{CrCOMT}$ from Carex rigescens increases salt stress and modulates melatonin synthesis in Arabidopsis thaliana. - Plant Cell Rep. 38: 1501-1514, 2019.

Zhang, K., Guo, N., Lian, L., Wang, J., Lv, S., Zhang, J.: Improved salt tolerance and seed cotton yield in cotton (Gossypium hirsutum L.) by transformation with bet $A$ gene for glycinebetaine synthesis. - Euphytica 181: 1-16, 2011.

Zhang, N., Sun, Q., Zhang, H., Cao, Y., Weeda, S., Ren, S.: Roles of melatonin in abiotic stress resistance in plants. - J. exp. Bot. 66: 647,2015 .

Zhang, N., Zhao, B., Zhang, H.J., Weeda, S., Yang, C., Yang,
Z.C., Ren, S., Guo, Y.D.: Melatonin promotes water-stress tolerance, lateral root formation, and seed germination in cucumber (Cucumis sativus L.). - J. Pineal Res. 54: 15-23, 2013.

Zhang, N., Zhao, B., Zhang, H.J., Weeda, S., Yang, C., Yang, Z.C., Shuxin, R., Guo, Y.D.: Melatonin promotes water stress tolerance, lateral root formation, and seed germination in cucumber (Cucumis sativus L.). - J. Pineal Res. 54: 15-23, 2012a

Zhang, N., Zhao, J., Yang, R.C.: Advances in melatonin and its functions in plants. - Agr. Sci. Tec. 13: 627-634, $2012 \mathrm{~b}$.

Zhang, T., Shi, Z., Zhang, X., Zheng, S., Wang, J., Mo, J.: Alleviating effects of exogenous melatonin on salt stress in cucumber. - Sci. Hort. 262: 109070, 2020.

Zhang, Y.P., Yang, S.J., Chen, Y.Y.: Effects of melatonin on photosynthetic performance and antioxidants in melon during cold and recovery. - Biol. Plant. 61: 571-578, $2017 \mathrm{~b}$.

Zhang, Z., Li, G., Gao, H., Zhang, L., Yang, C., Liu, P.: Characterization of photosynthetic performance during senescence in stay-green and quick-leaf-senescence, Zea mays L. inbred lines. - Plos ONE 7: e42936, 2012c.

Zhao, G., Zhao, Y., Yu, X., Kiprotich, F., Han, H., Guan, R., Wang, R., Shen, W.: Nitric oxide is required for melatonin-enhanced tolerance against salinity stress in rapeseed (Brassica napus L.) seedlings. - Int. J. mol. Sci. 19: 1912, 2018.

Zhao, Y., Qi, L.W., Wang, W.M., Saxena, P.K., Liu, C.Z.: Melatonin improves the survival of cryopreserved callus of Rhodiola crenulata. - J. Pineal Res. 50: 83-88, 2011.

Zheng, X., Tan, D.X., Allan, A.C., Zuo, B., Zhao, Y., Reiter, R.J., Wang, L., Wang, Z., Guo, Y., Zhou, J., Shan, D., Li, Q., Han, Z., Kong, J.: Chloroplastic biosynthesis of melatonin and its involvement in protection of plants from salt stress. - Sci. Rep. 7: 41236, 2017.

Zhou, X., Zhao, H., Cao, K., Hu, L., Du, T., Baluška, F., Zou, Z.: Beneficial roles of melatonin on redox regulation of photosynthetic electron transport and synthesis of D1 protein in tomato seedlings under salt stress. - Front. Plant Sci. 7: 1823,2016 